\title{
Egg parasitoid wasps as natural enemies of the neotropical stink bug Dichelops melacanthus
}

\author{
Raúl Alberto Laumann(1), Maria Carolina Blassioli Moraes(1), Joseane Padilha da Silva(1), \\ Afrânio Márcio Corrêa Vieira ${ }^{(2)}$, Samantha da Silveira ${ }^{(1)}$ and Miguel Borges ${ }^{(1)}$
}

(1)Embrapa Recursos Genéticos e Biotecnologia, Parque Estação Biológica, Avenida W5 Norte (Final), Caixa Postal 02372, CEP 70770-917 Brasília, DF, Brazil. E-mail: laumann@cenargen.embrapa.br, mcbmorae@cenargen.embrapa.br, joseane@cenargen.embrapa.br, sa.silveria@gmail.com, mborges@cenargen.embrapa.br (2)Universidade de Brasília, Departamento de Estatística, ICC Centro, Subsolo, Módulo 15, CEP 70910-900 Brasília, DF, Brazil. E-mail: afranio@unb.br.

\begin{abstract}
The objective of this work was to determine the potential of five species of Scelionidae wasps Telenomus podisi, Trissolcus basalis, Trissolcus urichi, Trissolcus teretis and Trissolcus brochymenae - as natural enemies of the neotropical stink bug Dichelops melacanthus, and to determine if the presence of eggs of other stink bug species influences the parasitism and development of the parasitoids. Two kinds of experiments were done in laboratory: without choice of hosts (eggs of D. melacanthus) and with choice (eggs of D. melacanthus and of Euschistus heros). Biological parameters, including proportion of parasitism, immature survivorship, progeny sex ratio, immature stage development period, and host preference were recorded. All the evaluated parasitoids can parasitize and develop on D. melacanthus eggs. The first choice of eggs did not influence the proportion of D. melacanthus eggs parasitized by Tr. basalis, Tr. teretis or Tr. brochymenae. However, D. melacanthus eggs as the first choice of Te. podisi and Tr. urichi increased, respectively, 9 and 14 times the chance for parasitism on eggs of this species. Behavioral and ecological aspects of parasitoids should be considered prior to their use in biological control programs.
\end{abstract}

Index terms: Telenomus, Trissolcus, biological control, corn pests, host preference, host suitability.

\section{Vespas parasitoides de ovos como inimigos naturais do percevejo neotropical Dichelops melacanthus}

Resumo - O objetivo deste trabalho foi determinar o potencial de cinco espécies de vespas Scelionidae Telenomus podisi, Trissolcus basalis, Trissolcus urichi, Trissolcus teretis e Trissolcus brochymenae -, como inimigos naturais do percevejo neotropical Dichelops melacanthus, e determinar se a presença de ovos de outras espécies de percevejo tem influência sobre o parasitismo e o desenvolvimento dos parasitoides. Foram realizados dois tipos de experimentos em laboratório: sem escolha de hospedeiros (ovos de D. melacanthus) e com escolha (ovos de D. melacanthus e de Euschistus heros). Foram registrados parâmetros biológicos que incluíram: proporção de parasitismo, sobrevivência de imaturos, razão sexual da progênie, tempo de desenvolvimento dos estágios imaturos e preferência de hospedeiro. Todas as espécies de parasitóides avaliadas podem parasitar e desenvolver-se em ovos de D. melacanthus. A escolha inicial de ovos não influenciou a proporção de ovos de D. melacanthus parasitados por Tr. basalis, Tr. teretis ou Tr. brochymenae. Entretanto, para Te. podisi e Tr. urichi, a escolha inicial por ovos de D. melacanthus aumentou em 9 e 14 vezes, respectivamente, a chance de parasitismo nesta espécie. Aspectos comportamentais e ecológicos dos inimigos naturais devem ser considerados antes de sua utilização em programas de controle biológico.

Termos para indexação: Telenomus, Trissolcus, controle biológico, pragas do milho, preferência de hospedeiro, disponibilidade do hospedeiro.

\section{Introduction}

Stink bugs are key pests for many crops due to the damage caused by their feeding habits and to the worldwide distribution of many species (Panizzi \& Slansky, 1985; Panizzi, 1997).

In South and Southwestern Brazil, the neotropical stink bug Dichelops melacanthus (Dallas) (Hemiptera:
Pentatomidae) is one of the major pests for corn (Zea mays L.) and wheat (Triticum aestivum L.), and a secondary pest for soybean [Glycine max (L.) Merill] (Ávila \& Panizzi, 1995; Chocorosqui \& Panizzi, 2004; Manfredi-Coimbra et al., 2005). The impact of D. melacanthus in cultivated areas has increased in recent years mainly because the extensive adoption

Pesq. agropec. bras., Brasília, v.45, n.5, p.442-449, maio 2010 
of crop rotation in no-tillage cultivation systems, favors stink bugs by offering a continuous food supply and by enhancing their ability to survive in adverse periods of the year (winter or dry seasons) under crop debris (Chocorosqui \& Panizzi, 2004; Carvalho, 2007).

The technology available for D. melacanthus management is based on chemical control with insecticides (Ávila \& Panizzi, 1995). Therefore, the development of alternative methods for population management, such as biological control, may help to reduce the pest impact in a more sustainable context.

Scelionidae egg parasitoid wasps are important natural enemies of stink bugs, and some species of this wasp family are being used in many countries for their biological control, especially the cosmopolitan Trissolcus basalis (Wollaston) and Telenomus podisi Ashmead (Clarke \& Walter, 1995; Corrêa-Ferreira \& Moscardi, 1996; Corrêa-Ferreira, 2002; Ehler, 2002). These parasitoid wasps have biological attributes and behavioral responses to host density that could lead to density-dependent parasitism and efficient local regulation of stink bug populations (Laumann et al., 2008). In Brazil, Corrêa-Ferreira \& Moscardi (1996) showed that inoculative liberation of Tr. basalis can control stink bug populations, and this technology is being used in microbasin production systems in Southern Brazil (Corrêa-Ferreira, 2002).

There is little understanding of natural parasitism by egg parasitoids in D. melacanthus. In Paraná state, Brazil, eggs of this species can be parasitized by Te. podisi, Tr. basalis, Trissolcus brochymenae (Ashmead), and Trissolcus urichi (Crawford) with parasitism indexes from 30 to $60 \%$ (Corrêa-Ferreira \& Moscardi, 1995). In the Western region of Brazil, Te. podisi has been registered attacking eggs of D. melacanthus (Carvalho, 2007). Other non-scelionid parasitoid insects registered on egg masses of D. melacanthus are: Ooencyrtus sp. (Hymenoptera: Encyrtidae), Neorileya ashmeadi (Crawford) and Neorileya sp. (Hymenoptera: Eurytomidae) (Corrêa-Ferreira \& Moscardi, 1995). Despite this information, there are no data on the biology and biological potential of these parasitoids in eggs of D. melacanthus.
The objective of this work was to study the biological aspects of five species of Scelionidae wasps parasitization on eggs of D. melacanthus, and to determine if the presence of eggs of other species of stink bug influence the parasitism and the development of the parasitoids.

\section{Materials and Methods}

Parasitoid wasp colonies were started with insects collected in soybean crops and natural vegetation in the Distrito Federal, Brazil $\left(15^{\circ} 47^{\prime} \mathrm{S}\right.$; $\left.47^{\circ} 55^{\prime} \mathrm{W}\right)$. The insects were reared in laboratory under continuous rearing for approximately 25 generations. The scelionid species selected for this study (Telenomus podisi, Trissolcus basalis, Tr. brochymenae, Tr. urichi) were previously reported attacking D. melacanthus and others species of stink bugs eggs such as Euschistus heros, Piezodorus guildinii and Nezara viridula in the field (Corrêa-Ferreira \& Moscardi, 1995; Medeiros et al., 1998). Although Trissolcus teretis (Johnson) was not reported using D. melacanthus as a host it was also selected because it is usually found in stink bug eggs in Central Brazil (Medeiros et al., 1998).

The parasitoids were maintained using eggs of the brown stink bug Euschistus heros (Fabricius) as hosts, in a controlled environmental chamber in plastic cages, $25-\mathrm{cm}^{2}$ flask tissue culture, angled neck, (ICN Biomedicals, Irvine, USA). Host eggs were exposed to parasitoids for 24 hours and then removed and placed in glass tubes, $7.5 \mathrm{~cm}$ longx $1.3 \mathrm{~cm}$ diameter, for incubation. Droplets of honey were offered to adult wasps as food.

Euschistus heros and D. melacanthus were reared on sunflower, Helianthus annuus (L.), soybean, raw peanut, Arachis hypogaea L., and seeds and pods of green bean, Phaseolus vulgaris L. Dichelops melacanthus were also fed on Chinese privet, Ligustrum lucidum Aiton. Separate 8-L plastic containers were used for nymphs and adults. The eggs were collected daily and separated in Petri dishes until nymph emergence. Stink bugs and parasitoids were both reared under 14-hours photophase at $26.0 \pm 1{ }^{\circ} \mathrm{C}$ and $65 \pm 10 \%$ relative humidity. The E. heros colony 
was started from insects collected in soybean and in natural vegetation in Distrito Federal, Brazil, and the D. melacanthus colony was started from insects from the entomology laboratory of Embrapa Soja, previously collected in Londrina, Paraná state, Brazil.

To test the capacity of each parasitoid species to successfully parasitize and develop using D. melacanthus as a host, egg masses from the laboratory colony with 20 eggs were offered to females of each parasitoid species $(n=20$ for each parasitoid species, using one egg mass per parasitoid female). The insects used in the experiment were naive females with 24 to 48 hours at the adult stage, which were maintained for 24 hours with males for copulation before the experiments were initiated. Egg masses and parasitoid females were placed in plastic Petri dishes $(4.5 \mathrm{~cm}$ diameter) in a rearing chamber, under the same conditions described above; a droplet of honey was added as food for the wasps. After 24 hours, the parasitoids were removed from the arena and the egg masses were maintained in the rearing chamber for evaluations of parasitism and development of parasitoid immature stages. Daily observations under stereoscopic microscopy Zeiss SV6, (Carl Zeiss Microimaging GmBh, Munich, Germany) were performed to evaluate the number of parasitized eggs, number of parasitoids emerged from egg masses, sex ratio of the progeny, and immature stage development period. These data were used to calculate: parasitism (number of parasitized eggs per number of eggs offered), estimated by color change (Medeiros et al., 1998); immature survivorship, which is the proportion of eggs that successfuly complete the immature development (number of adults per number of egg parasitized); sex ratio (number of females/ total number of progeny); and immature stage development period (days from the parasitism of the eggs to adult emergence). When egg color did not offer a clear indication and the parasitoid did not complete development, the eggs were dissected under stereoscopic microscopy in order to confirm parasitism.

To evaluate how the parasitoids recognize and select $D$. melacanthus eggs in the presence of another host, an E. heros egg mass was offered along with the D. melacanthus egg mass. Both egg masses contained the same number of eggs: 20 eggs per mass. This experiment was carried out following the same procedures as described before. To determine if the parasitoid species showed any host first choice preference, the movements of female wasps in the arenas was observed until they chose one of the egg masses offered, made physical contact with it and drummed it with their antennas for at least 60 seconds. The alternative host E. heros was selected because it is one of the most common stink bugs species of cultivated areas in Brazil.

Parasitism preference was evaluated by maintaining the parasitoid females for a period of 12 hours in the arenas. After this time, they were removed, the egg masses were separated by host species in Petri dishes, and the egg masses were observed daily to compute the number of eggs of each parasitized host and the number of parasitoids emerging from the egg masses of each host. With these data, calculations were performed for each egg mass and host and parasitoid species, and the parasitism and immature survivorship was determined as described above.

The mean proportion of parasitism, immature survivorship and sex ratio (proportion of females) of the different parasitoid species were analysed using generalized linear models (GLM) (Lee et al., 2006) with binomial distribution and $\log$ link function. When overdispersion of the data was observed, a quasi-likelihood method was used to estimate the heterogeneity factor. Multiple comparisons through orthogonal contrasts were made to determine which means were significantly different, and Bonferroni error corrections were applied. Immature stage development period (days) was analysed by Kruskal Wallis ANOVA and Dunn's multiple comparison test to evaluate significance between mean values of the parasitoid species.

Parasitoid first choice in the experiments with two hosts were analyzed using generalized linear models (GLM) with binomial distribution and logit link function, and an estimate of $D$. melacanthus egg mass choosing probability was calculated. The hypothesis of nonpreference (50\% of choice for egg masses of each stink bug species) was 
tested by the $\chi^{2}$ Wald test. The mean proportion of parasitism and immature survivorship, in each combination of host/parasitoid in the experiment with possibility of host choice were compared using GLM analyses, as described above. Additionally, to study if the parasitoid first choice influenced the number of parasitized eggs of each host, GLM analyses were done using first choice as covariate, and number of parasitized eggs as response variable. A binomial distribution was adjusted to the response variable, and a quasi-likelihood method to the heterogeneity factor estimation was applied to correct for data overdispersion. From this model, the odds ratios and their confidence interval $(95 \%)$ were calculated to determine the chance, after the parasitoid first choice, to parasitize D. melacanthus eggs instead of E. heros eggs, that is: the odds ratio was calculated to estimate the possible influence of the first selection of a host on the number of parasitized eggs of $D$. melacanthus. All tests were performed at $5 \%$ significance level.

\section{Results and Discussion}

All the studied parasitoid species successfully parasitized and developed on eggs of D. melacanthus. The mean proportion of parasitized eggs only differed between $T r$. urichi and Te. podisi, and the first species showed a significantly higher proportion of parasitism (Table 1). Immature survivorship was different between Tr. brochymenae and Tr. basalis, with the last one showing lower survivorship. The sex ratio of the progeny was mostly female biased, except for $T r$. urichi. The immature development period varied from 11 to 13 days and was significantly different among the species, except between Tr. basalis and Tr. urichi.
The parasitoids showed a differential ability to identify and use D. melacanthus eggs as a suitable host, and the proportion of parasitism reported here, for some of the species, showed differences with the parasitism previously reported in other hosts (Pacheco \& Corrêa-Ferreira, 1998; Sujii et al., 2002; Laumann et al., 2008). Nevertheless, the present work corroborates previous observations for different species of Scelionidae (Kivan \& Kilic, 2002, 2004), indicating that, despite being oligophagous or polyphagous (Austin et al., 2005), scelionid wasps show variability in their ability to recognize and select different species of stink bugs as hosts. Interestingly, D. melacanthus was shown to be a suitable host for Tr. teretis, a species not recorded previously as parasitizing eggs of this stink bug in the field.

When eggs of $E$. heros and D. melacanthus were offered at the same time, Te. podisi, Tr. teretis and $T r$. brochymenae showed a significant first choice preference for eggs of E. heros $\left(\chi^{2}=5.00, p=\right.$ $0.03 ; \chi^{2}=5.56, p=0.02$; and $\chi^{2}=8.89, p=0.003$, respectively). However, Te. basalis and Tr. urichi showed no preference for eggs of either stink bug species (Figure 1).

Trissolcus brochymenae parasitized a higher proportion of E. heros eggs (Figure 2 A). This species was the only one to show a difference in the proportion of parasitized eggs according to the host. However, immature survivorship was higher in E. heros eggs for Te. podisi, Tr. urichi, Tr. teretis and Tr. brochymenae (Figure 2 B). The preference observed for E. heros eggs by these species could be related to the higher survival of the immature stage of these parasitoids in E. heros eggs. Trissolcus basalis and Tr. urichi showed no host preference, and this could be related to the preference of these species for other stink bugs, such as Nezara viridula and Chinavia spp., respectively (Sujii et al., 2002). The continuous

Table 1. Biological parameters of five egg parasitoids species on Dichelops melacanthus eggs ${ }^{(1)}$.

\begin{tabular}{|c|c|c|c|c|}
\hline Species & Proportion of parasitism & Immature survivorship (proportion) & Sex ratio (proportion of females) & Development períod (days) \\
\hline Telenomus podisi & $0.41 \pm 0.38 \mathrm{a}$ & $0.64 \pm 0.39 \mathrm{ab}$ & $0.78 \pm 0.17 \mathrm{a}$ & $13.24 \pm 0.85 \mathrm{a}$ \\
\hline Trissolcus basalis & $0.71 \pm 0.38 \mathrm{ab}$ & $0.64 \pm 0.23 a$ & $0.53 \pm 0.23 \mathrm{ab}$ & $11.25 \pm 0.97 \mathrm{~b}$ \\
\hline Trissolcus urichi & $0.89 \pm 0.17 b$ & $0.60 \pm 0.20 \mathrm{ab}$ & $0.49 \pm 0.18 b$ & $11.74 \pm 0.74 b$ \\
\hline Trissolcus teretis & $0.62 \pm 0.46 \mathrm{ab}$ & $0.69 \pm 0.24 \mathrm{ab}$ & $0.77 \pm 0.11 \mathrm{a}$ & $12.38 \pm 0.49 \mathrm{c}$ \\
\hline Trissolcus brochymenae & $0.74 \pm 0.30 \mathrm{ab}$ & $0.80 \pm 0.21 \mathrm{~b}$ & $0.69 \pm 0.18 \mathrm{a}$ & $12.03 \pm 0.18 \mathrm{~d}$ \\
\hline
\end{tabular}

${ }^{(1)}$ Means \pm standard deviation followed by equal letters do not differ by Dunn's multiple comparison test, at $5 \%$ probability. 
rearing of the parasitoids in E. heros eggs does not appear to modify the host preference. Scelionidae wasps show an innate host preference (Sujii et al., 2002), and if the rearing in a host had any influence, the preferential first choice for E. heros eggs would be observed in all the species. These results agree with those found by Pacheco \& Corrêa-Ferreira (1998), Sujii et al. (2002) and Kivan \& Kilic $(2002,2004)$ for other stink bug and scelionid wasp combinations.

The selective response toward a specific host (E. heros) for three of the five species evaluated could suggest that these parasitoids use cues from host egg masses to identify those that would

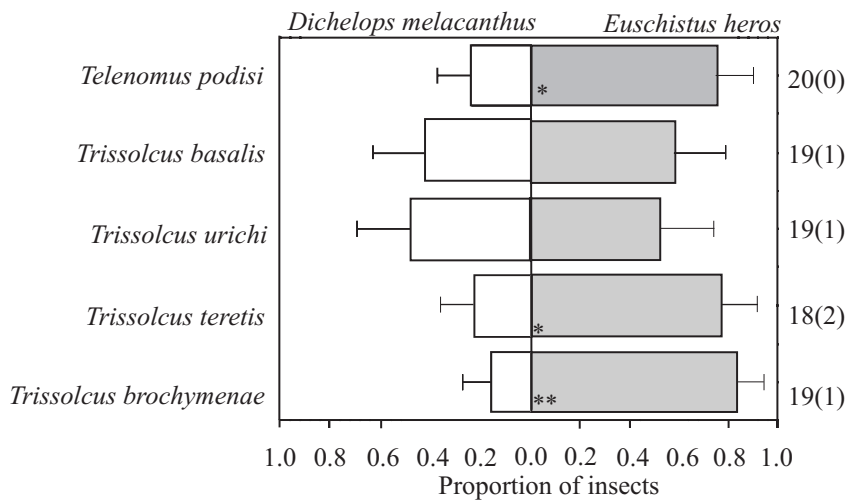

Figure 1. First choice of the parasitoid species evaluated in experiments with two hosts (Euschistus heros and Dichelops melacanthus). Bars indicate the $95 \%$ confidence interval. Numbers on the right side on the figures are the total number of replicate insects tested. Numbers in brackets represent the number of insects that did not respond to the treatment tested. * and ** Significant by the $\chi 2$ Wald test, respectively at 5 and $1 \%$ probability.

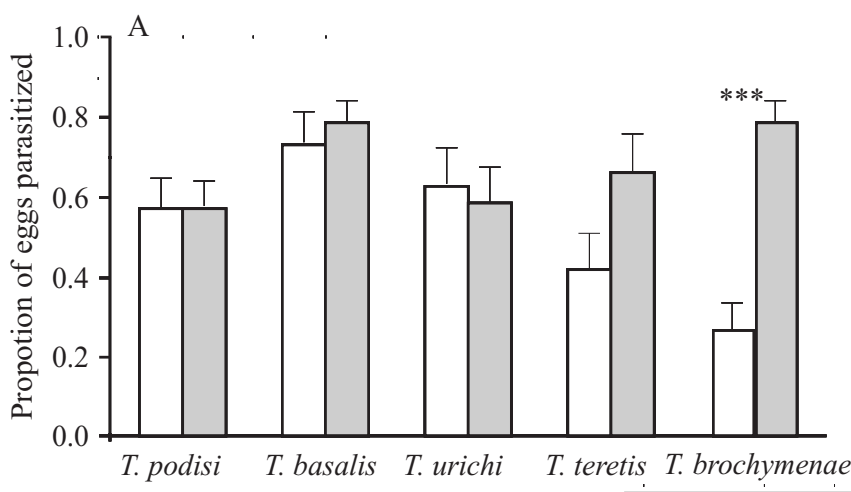

Dichelops melacanthus maximize their reproductive success. These cues could be related to physical (color, size, number and disposition of eggs, chorion thickness, corion ornamentation) and chemical (semiochemical) characteristics of the egg masses (Bin et al., 1993; Borges et al., 1999).

When the parasitoid female first choice was related to the number of eggs of each host, the first choice of $T e$. podisi had a significant influence in the number of $D$. melacanthus eggs parasitized (Table 2 and Figure $3 \mathrm{~A}$ ). The chance, estimated by the odds ratio, to parasitize eggs of D. melacanthus increased nine times when the first choice was for eggs of this species (Table 2). The number of $D$. melacanthus eggs parasitized by $T r$. urichi was also significantly influenced by the female first choice (Table 2 and Figure $3 \mathrm{C}$ ), and first choice increased the chance of parasitizing eggs of this species by approximately 14 times.

For Tr. basalis, Tr. teretis and Tr. brochymenae, the first choice of the females did not influence the number of parasitized eggs of D. melacanthus or E. heros. However, for Tr. teretis the proportion of E. heros parasitized eggs after the female choice was marginally nonsignificant (Table 2 and Figure $3 \mathrm{~B}, \mathrm{D}$ and $\mathrm{E}$ ).

The proportion of eggs parasitized by scelionid wasps in different hosts may be modified by the presence of two or more hosts (Pacheco \& Corrêa-Ferreira, 1998; Sujii et al., 2002), in some cases increasing parasitism on nonpreferred hosts (Pacheco \& Corrêa-Ferreira, 1998). The results of the present work showed that, even in the presence of an alternative host, used to rear parasitoids in

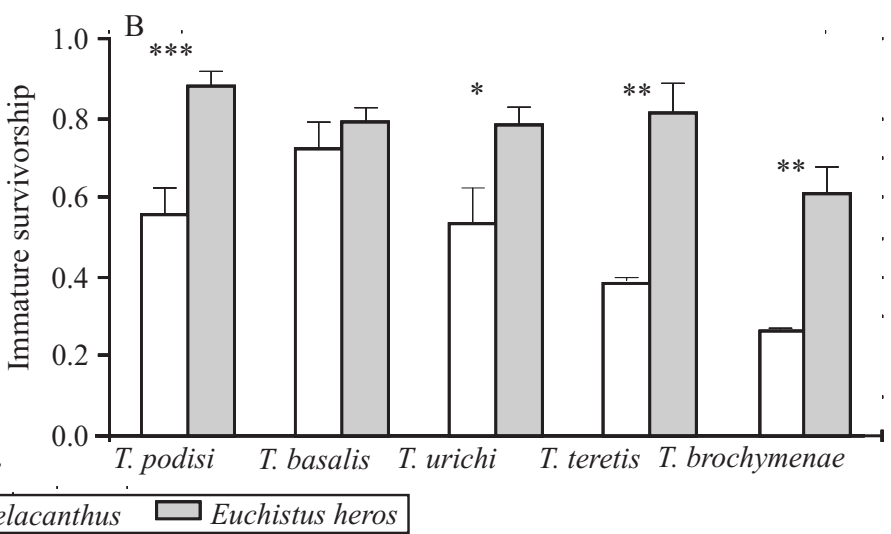

Figure 2. Mean $\_$standard-error of: A, proportion of parasitized eggs; B, immature survivorship of different parasitoids on Euschistus heros or Dichelops melacanthus egg mass. *** and *** Significant by GLM analyses respectively by 5,1 and $0.1 \%$. 
the laboratory during several generations, the first choice of hosts in three out of the five species did not affect the parasitism in D. melacanthus eggs.

However, the effect of the first and second trophic level in the foraging behaviour of the parasitoids could modify the host/parsitoid interaction. For the plant-stink bug-scelionid wasp trophic system, it has been shown that volatile substances of different plant species, induced by different stink bugs, can act as synomones attracting females of Tr. basalis (Colazza et al., 2004) or Te. podisi (Moraes et al., 2005, 2008). In addition, there is also some evidence that these parasitoids may selectively respond to semiochemicals from stink bugs (Borges et al., 2003; Conti et al., 2004; Salerno et al., 2006; Silva et al., 2006; Laumann et al., 2009) or substrate-borne vibratory signals used in the stink bug sexual communication (Laumann et al., 2007).

The Scelionidae species evaluated in this work are potentially effective natural enemies of D. melacanthus. At least Tr. basalis, Tr. teretis and Tr. brochymenae have this potential and could be used in areas where populations of this stink bug species co-exist with other ones. However, before using these parasitoids in biological control of D. melacanthus, specific information about mass rearing, host search behavior in different host densities and influence of different species

Table 2. Probability of five scelionid wasps to parasitize Dichelops melacanthus eggs instead of Euschistus heros eggs, estimated by the odds ratio.

\begin{tabular}{lccc}
\hline $\begin{array}{l}\text { Parasitoid } \\
\text { first choice }\end{array}$ & $\begin{array}{c}\text { Odds } \\
\text { ratio }\end{array}$ & $\begin{array}{c}\text { Confidence } \\
\text { Interval (95\%) }\end{array}$ & Significance \\
\hline Euschistus heros & 0.5617 & $\begin{array}{c}\text { Telenomus podisi } \\
0.7966-3.9780\end{array}$ & 0.4732 \\
Dichelops melacanthus & 9.2579 & $3.1858-26.9030$ & 0.0370 \\
\hline & \multicolumn{4}{c}{ Trissolcus basalis } \\
Euschistus heros & 0.4834 & $0.2684-0.8706$ & 0.2170 \\
Dichelops melacanthus & 4.5251 & $1.5158-13.5083$ & 0.1675 \\
\hline & 0.5491 & $0.2023-1.4899$ & 0.5480 \\
Euschistus heros & 14.9041 & $4.6239-48.0398$ & 0.0210 \\
Dichelops melacanthus & \multicolumn{4}{c}{ Trissolcus teretis } \\
\hline & 0.0882 & $0.0239-0.3250$ & 0.0626 \\
Euschistus heros & 0.2728 & $0.0809-0.9200$ & 0.2853 \\
Dichelops melacanthus & \multicolumn{4}{c}{ Trissolcus brochymenae } \\
\hline & 0.8376 & $0.3291-2.1314$ & 0.8495 \\
Euschistus heros & 0.7330 & $0.2343-2.2933$ & 0.7850 \\
Dichelops melacanthus &
\end{tabular}
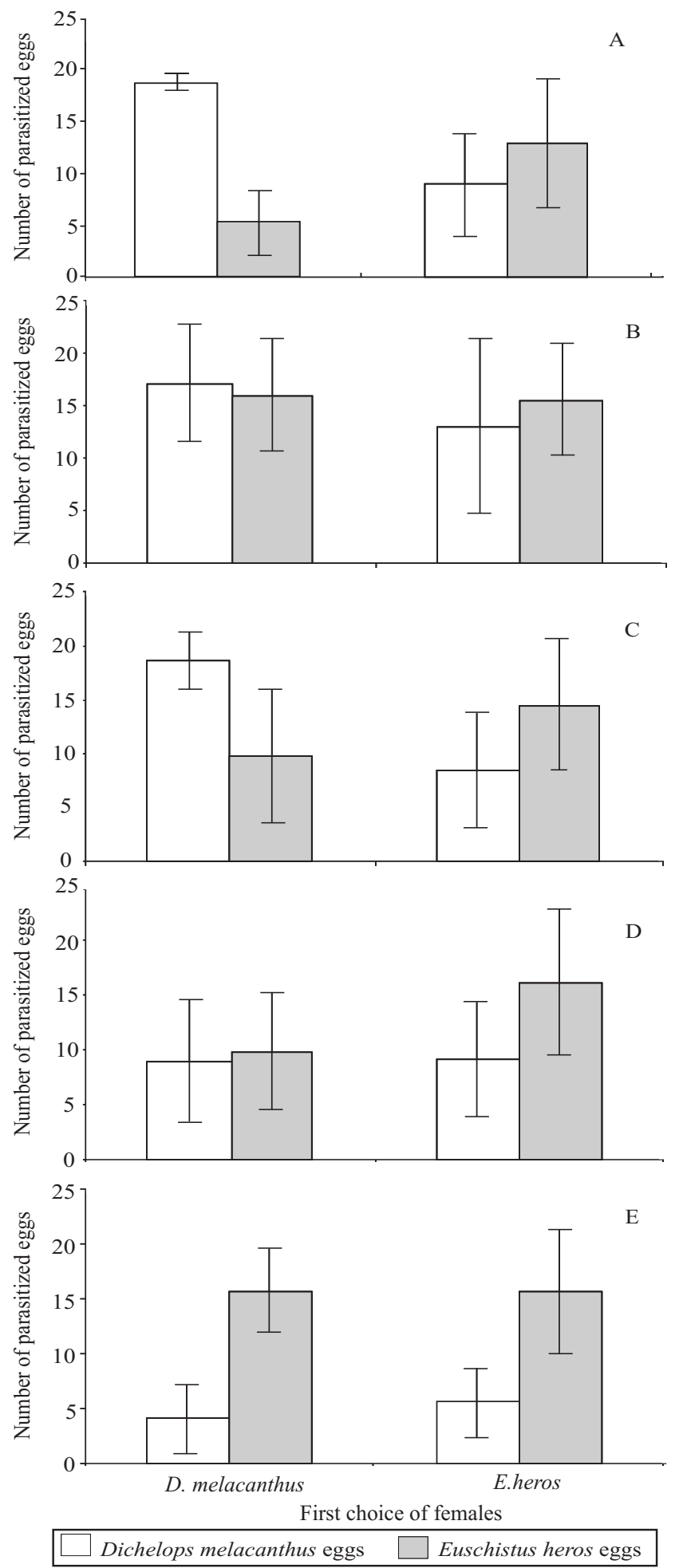

Figure 3. Relation between first choice of the parasitoid females and number of parasitized eggs (mean \pm standard deviation), in experiments where the two hosts were offered simultaneously to the parasitoids. A, Telenomus podisi; B, Trissolcus basalis; C, Trissolcus urichi; D, Trissolcus teretis; and E, Trissolcus brochymenae. 
complexes in tri-trophic interactions, as well as other relevant biological and ecological aspects need to be established.

\section{Conclusions}

1. Scelionidae wasps may successfully use Dichelops melacanthus eggs as hosts.

2. The parasitoids show interspecific behavioral differences.

3. For Trissolcus basalis, Trissolcus teretis and Trissolcus brochymenae, the presence of eggs of different species of stink bugs does not influence the performance of the parasitoids, evaluated on Dichelops melacanthus.

\section{Acknowledgements}

To the Conselho Nacional de Desenvolvimento Científico e Tecnológico, Fundação de Amparo à Pesquisa do Distrito Federal and Empresa Brasileira de Pesquisa Agropecuária, for financial support; to Hélio Moreira dos Santos and Dia Tiburcio, for helping with the field collection and laboratory rearing of the insects used in this study; and to Dr. Mark Horn, International Consultant at Embrapa Recursos Genéticos e Biotecnologia, for text revision and comments that improved the manuscript.

\section{References}

AUSTIN, A.D.; JOHNSON, N.F.; DOWTON, M. Systematics, evolution, and biology of scelionid and platygastrid wasps. Annual Review of Entomology, v.50, p.553-582, 2005.

ÁVILA, C.J.; PANIZZI, A.R. Occurrence and damage by Dichelops (Neodichelops) melacanthus (Dallas) (Heteroptera: Pentatomidae) on corn. Anais da Sociedade Entomológica do Brasil, v.24, p.193-194, 1995.

BIN, F.; VINSON, S.B.; STRAND, M.R.; COLAZZA, S.; JONES JUNIOR, W.A. Source of an egg kairomone for Trissolcus basalis, a parasitoid of Nezara viridula. Physiological Entomology, v.18, p.7-15, 1993.

BORGES,M.;COLAZZA, S.;RAMIREZ-LUCAS,P.;CHAUHAN, K.R.; MORAES, M.C.B.; ALDRICH, J.R. Kairomonal effect of walking traces from Euschistus heros (Heteroptera: Pentatomidae) on two strains of Telenomus podisi (Hymenoptera: Scelionidade). Physiological Entomology, v.28, p.349-355, 2003.

BORGES, M.; COSTA, M.L.M.; SUJII, E.R.; CAVALCANTI, M. das G.; REDÍGOLO, G.F.; RESCK, I.S.; VILELA, E.F. Semiochemical and physical stimuli involved in host recognition by Telenomus podisi (Hymenoptera: Scelionidae) toward Euschistus heros (Heteroptera: Pentatomidae). Physiological Entomology, v.24, p.227-233, 1999.

CARVALHO, E. da S.M. Dichelops melacanthus (Dallas, 1851) (Heteroptera: Pentatomidae) no sistema de plantio direto no sul do Mato Grosso do Sul: flutuação populacional, hospedeiros e parasitismo. 2007. 57p. Tese (Mestrado) - Universidade Federal da Grande Dourados, Dourados.

CHOCOROSQUI, V.R.; PANIZZI, A.R. Impact of cultivation systems on Dichelops melacanthus (Dallas) (Heteroptera: Pentatomidae) population and damage and its chemical control on wheat. Neotropical Entomology, v.33, p.487-492, 2004.

CLARKE, A.R.; WALTER, G.H. "Strains" and the classical biological control of insect pests. Canadian Journal of Zoology, v.73, p.1777-1790, 1995.

COLAZZA, S.; FUCARINO, A.; PERI, E.; SALERNO, G.; CONTI, E.; BIN, F. Insect oviposition induces volatile emission in herbaceous plants that attracts egg parasitoids. Journal of Experimental Biology, v.207, p.47-53, 2004.

CONTI, E.; SALERNO, G.; BIN, F.; VINSON, S.B. The role of host semiochemicals in parasitoid specificity: a case study with Trissolcus brochymenae and Trissolcus simoni on pentatomid bugs. Biological Control, v.29, p.435-444, 2004.

CORRÊA-FERREIRA, B.S. Trissolcus basalis para o controle de percevejos da soja. In: PARRA, J.R.P.; BOTELHO, P.S.M.; CORRÊA-FERREIRA, B.S.; BENTO, J.M.S. (Ed.). Controle biológico no Brasil: parasitóides e predadores. São Paulo: Manole, 2002. p.449-476

CORREAA-FERREIRA, B.S.; MOSCARDI, F. Biological control of soybean stink bugs by inoculative releases of Trissolcus basalis. Entomologia Experimentalis et Applicata, v.79, p.1-7, 1996.

CORRÊA-FERREIRA, B.S.; MOSCARDI, F. Seasonal occurrence and host spectrum of egg parasitoids associated with soybean stink bugs. Biological Control, v.5, p.196-202, 1995.

EHLER, L.E. An evaluation of some natural enemies of Nezara viridula in northern California. Biocontrol, v.47, p.309-325, 2002.

KIVAN, M.; KILIC, N. Host preference: parasitism, emergence and development of Trissolcus semistriatus (Hym., Scelionidae) in various host eggs. Journal of Applied Entomology, v.126, p.395-399, 2002

KIVAN, M.; KILIC, N. Parasitism and development of Trissolcus simoni in eggs of different host species. Phytoparasitica, v.2, p.57-60, 2004.

LAUMANN, R.A.; AQUINO, M.F.S.; MORAES, M.C.B.; PAREJA, M.; BORGES, M. Response of the egg parasitoids Trissolcus basalis and Telenomus podisi to compounds from defensive secretions of stink bugs. Journal of Chemical Ecology, v.35, p.8-19, 2009

LAUMANN, R.A.; MORAES, M.C.B.; ČOKL, A.; BORGES, M. Eavesdropping on sexual vibratory signals of stink bugs (Hemiptera: Pentatomidae) by the egg parasitoid Telenomus podisi. Animal Behaviour, v.73, p.637-649, 2007.

LAUMANN, R.A.; MORAES, M.C.B.; PAREJA, M.; BOTELHO, A.C.; MAIA, A.N.A.; LEONARDECZ E.; BORGES, M. 
Comparative biology and functional response of Trissolcus spp. (Hymenoptera: Scelionidae) and implications for stink bugs (Hemiptera: Pentatomidae) biological control. Biological Control, v.44, p.32-41, 2008.

LEE, Y.; NELDER, J.A.; PAWITAN, Y. Generalized linear models with random effects: unified analysis via H-likelihood. London: Chapman \& Hall, 2006. 396p.

MANFREDI-COIMBRA, S.; SILVA, J.J. da; CHOCOROSQUI, V.R.; PANIZZI, A.R. Danos do percevejo barriga-verde Dichelops melacanthus (Dallas) (Heteroptera: Pentatomidae) em trigo. Ciência Rural, v.35, p.1243-1247, 2005.

MEDEIROS, M.A. de; LOIÁCONO, M.S.; BORGES, M.; SCHMIDT, F.V.G. Incidência natural de parasitóides em ovos de percevejos (Hemiptera: Pentatomidae) encontrados na soja no Distrito Federal. Pesquisa Agropecuária Brasileira, v.33, p.1431-1435, 1998.

MORAES, M.C.B.; LAUMANN, R.A.; SUJII, E.R.; PIRES, C.; BORGES, M. Induced volatiles in soybean and pigeon pea plants artificially infested with the neotropical brown stink bug, Euschistus heros, and their effect on the egg parasitoid, Telenomus podisi. Entomologia Experimentalis et Applicata, v.115, p.227-237, 2005.

MORAES, M.C.B.; PAREJA, M.; LAUMANN, R.A.; HOFFMANN-CAMPO, C.B.; BORGES, M. Response of the parasitoid Telenomus podisi to induced volatiles from soybean damaged by stink bug herbivory and oviposition. Journal of Plant Interactions, v.3, p.111-118, 2008.

PACHECO, D.J.P.; CORRÊA-FERREIRA, B.S. Potencial reprodutivo e longevidade do parasitóide Telenomus podisi Ashmead, em ovos de diferentes espécies de percevejos. Anais da Sociedade Entomológica do Brasil, v.27, p.585-591, 1998.

PANIZZI, A.R. Wild hosts of pentatomids: ecological significance and role in their pest status crops. Annual Review of Entomology, v.42, p.99-122, 1997.

PANIZZI, A.R.; SLANSKY JR., F. Review of phytophagous pentatomids (Hemiptera: Pentatomidae) associated with soybean in the Americas. Florida Entomologist, v.68, p.184-214, 1985.

SAlERNO, G.; CONTI, E.; PERI, E.; COLAZZA, S.; BIN, F. Kairomone involvement in host specificity of the egg parasitoid Trissolcus basalis (Hymenoptera: Scelionidae). European Journal of Entomology, v.103, p.311-318, 2006.

SILVA, C.C.; MORAES, M.C.B.; LAUMANN, R.A.; BORGES, M. Sensory response of the egg parasitoid, Telenomus podisi to stimuli from the bug, Euschistus heros. Pesquisa Agropecuária Brasileira, v.41, p.1093-1098, 2006.

SUJII, E.R.; COSTA, M.L.M.; PIRES, C.S.S.; COLAZZA, S.; BORGES, M. Inter and intra-guild interactions in egg parasitoid species of the soybean stink bug complex. Pesquisa Agropecuária Brasileira, v.37, p.1541-1549, 2002.

$\overline{\text { Received on March 31, } 2010 \text { and accepted on April 30, } 2010}$ 